Volume 2, Nomor 2, Desember 2021

\title{
SAME-SEX LOVE AS CHALLENGE TO COWBOY'S MASCULINITY PRESENTED IN ANG LEE'S BROKEBACK MOUNTAIN
}

\author{
Atinia Hidayah $^{1}$, M. Elfan Kaukab ${ }^{2}$
}

\begin{abstract}
Cowboy and his natures have made contribution to the creation of definite masculinity and love relationship between cowboys in Brokeback Mountain affects how cowboy's masculinity is further depicted. This paper has purpose to reveal how same-sex relationship in the movie challenges the cowboy's masculinity by analysing the subtitle. This study applied semiotics theory to identify the available data relevant to the construction meaning of cowboy's masculinity, myth of romantic love and homosexuality. The result shows that homosexual relationships between major cowboy characters in the movie contest the long-established masculinity of cowboy. The struggle to maintain traditional relationship through marriage does not affect social prejudice towards homosexual cowboy.
\end{abstract}

Keywords: cowboy, homosexuality, love, same-sex

\footnotetext{
${ }^{1}$ Faculty of Language and Literature, Universitas Sains Al-Quran Jawa Tengah, Wonosobo, Indonesia. Email: atiniahidayah@unsiq.ac.id

${ }^{2}$ Faculty of Economics and Business, Universitas Sains Al-Quran Jawa Tengah, Wonosobo, Indonesia. Email: elfan@unsiq.ac.id
}

\section{INTRODUCTION}

The change of social condition in America in 1960s involved some significant movements which brought about a big change to the life of American society. The feminist movement, black people movement for equality, and even the homosexuality movement for its approval had turned to be a new start for the change of American social life and had influenced the history of America until the present days.

Some movements had reached the satisfying goal but some of them still carry out the struggle for the goal in recent years. The disagreement of some movement's approval includes many factors, such as religious, socio-cultural, psychological, and some other factors that stated the impossibility of the approval. One of big issues that still overcome pro and contra today, not only in America but almost in entire world, is homosexuality. The existence of homosexuals arises many debates which come from many sides. The struggle for their approval is still continuing even though there are also many groups that refuse homosexuality to exist in society. Disagreements of homosexuality arise by indicating it as uncommon relationship. In widespread society the common relationship between human being is called heterosexuality, which means the relationship between man and woman.

In America, homosexuals participate in the movement of the equality of human right since the past years until the present day. Public's refusal not only covers the present time but it badly influences the existence of homosexuality in the past, such as in cowboy era. Cowboy has become one of American icons and myths and is famous 
with their interesting way of life in western civilization.

Herding cattle as a tough occupation becomes one of their characteristics, the way they dress up with special clothes and unique attributes are also the other significant parts of cowboy represent the characteristics of cowboy's masculinity. Those characteristics enrich the cowboy image and differentiate them from other American icons. The brief explanation about cowboy's life represents the cowboy's masculinity because their life as a cowboy illustrates man domination and power. In addition, cowboy lives in fairly conservative circle where social aspects are strongly respected by society. Since social prejudice is extremely one of important factors that affects the life of cowboy, infraction to any norms may cause fatal penalty, including having a homosexual relationship.

\section{LITERARY REVIEW}

\section{Homosexuality in 1960s}

Homosexuality, during many decades, has spread almost all over the world including America. Homosexuality in America also found its difficulty in drawing the exact period concerning the beginning of homosexuality similar to the Greek history in relation to its first homosexuality. European colony arrived in North America in 1600 and built their first settlements on this land after the arrival of Spanish which was dominating Mexico, West Indian, and South America. They moved from England to this continent with the purposes of religious and political freedom, adventuring, and attaining a better living. The first colony landed in In Jamestown which was then called New World, in 1607. Furthermore, this first colony arrival was recognized brought the influence of homosexuality in America.

The political, social changes, cultural and many infamous movements had emerged in 1960s. All through 1950s and 1960s, homosexuality had been positioned as moral panic as media reported intensely and heavily about them conserving them to bring high anxiety to society. This was also accompanied by numbers of police arrests of homosexuals. The1969 Stonewall riots had initiated the beginning period of gay activism, lesbians and gay men for the struggle of their recognition and acknowledgment. The first major national debates concerning gay rights had appeared during the campaign in 1977 and 1978 (Fejes, 2008).

\section{American Myth of Romantic Love}

Americans live in culture that grows time to time and this developed culture forms an American cultural mindset. This mindset is influenced by the history of the present and future. This growing mindset is then developed into myth. According to Jack Nachbar and Kevin Lause, myth is repeatedly applied to give definition a mistake or error which then for particular reasons to be accepted as true (Nachbar and Lause, 1992). In the modern culture, which is afterward thought out an idea of popularculture, myth is described as belief or value that is significant and long lasting andwidely accepted as being true. In other words, for American, myth is a cultural beliefthat has been created in their mind through their historical experience that influences them in seeing something. The American myth has changed the world point of view about America.

Out of many interesting myths to discuss is myth of romantic love. It is pointed out that every individual has a single perfect partner whom complete life and make it permanent to create possible happiness (Nachbar and Lause, 1992). The addition argued that the historical background of the myth of romantic love emerged with the arrival of the Puritan in the early year of American history. In that time, myth of romantic love wasbasically relationship 
between man and woman that was vowed in a marital relationship based on religious standard (Nachbar and Lause, 1992). The orientation of the marriage was very simple for Puritan, which was to continue their generation. Myth of romantic love that they had was naturally focused on religious norm, they did sexual intercourse just to get children and eroticism wasobviously refused on their mindset. The main aim of the marriage which is to have children produces the significant point about traditional myth of romantic love. The comprehension of the term love takes manypoints of views. Love is simplified into several definitions: First, love is an emotion of human feeling that affects their mind and attitudes. Second, being loved isan ultimate emotional high that meeting human's mind and body, and the ultimatestate of personal fulfilment and happiness.

\section{Cowboy Myth}

Cowboy gives an ever lasting impression on the American memory as they have given a certain characteristic to American history for their interesting way of life. Cowboy is usually related to ranches and cattle since these become their main job. In the early American, in 18 century, the word "cowboy" was pronounced as two words "cow boys", which has meaning person who herded cattle. The business of cattle and cowboy's life contribute to the production of America's potent myth and from the circumstance surrounding cowboy's life, he achieves this significance. Thus, cowboy becomes the symbol of courage, honour, chivalry and also individualism (Savage, 1993).

Cowboy is famous with their hard and lonely life because of the ranch work they do, and this produces the idea cowboy as the symbol of individualism. Their job which is not involving many people, like moving cattle and herding them, support their lonely days. The isolated condition in doing the work result the self-dependence and individualism. Additionally, cowboy emerges as a folk hero who possessed great reserves of natural wisdom, a real desire for adventure and fortune. The story of how the cattle moved from Texas across the Kansas and later of Nebraska is very famous and this caused cowboy to ne said as hero on horseback (Encyclopaedia Americana Volume 8, 2004). These natures of cowboy characterize his masculinity.

\section{Semiotics}

In relation with myth, Barthes explained that there is the tri-dimensional pattern: the signifier, the signified, and the sign. $\mathrm{He}$ stated that myth is a peculiar system that is constructed from a semiological chain which existed before it: it is a secondorder semiological system (Barthes, 1999). In language, sign is formed from signifier and signified and the sign in this language becomes the signifier in myth. Furthermore, the sign in myth has the connotative meaning. Regarding the sign in film, Metz argued that the construction of meaning in film involve the idea that signifier and signified are almost identical in which the sign of cinema is a shortcircuit sign (Metz in Monaco, 2000).

\section{METHODOLOGY}

This research identified scenes and subtitle with content of homosexuality, myth of romantic love and cowboy myth in Ang Lee's Brokeback Mountain released in 2005 by Focus Feature LLC and River Road Entertainment. This descriptive qualitative applies library research technique that uses books and other writing material to support the subject matter of the research. Qualitative method is applied for exploring and comprehending the meaning individuals or groups attribute to social or human matters (Cresswell, 2009).

The data were gained by watching the movie repeatedly in order to figure out and understand the message brought in. The 
classification of data was done afterward with the purpose to collect relevant data which are related to the research questions. After data were collected, they were studied and arranged in terms of relatedness to the research. Then, the classified data were interpreted using theories and approached needed.

\section{RESULT AND DISCUSSION}

This section tries to describe the challenge to the American cowboy myth exists in the movie through the characters' cowboy masculine features and their homosexuality. The time setting in Brokeback Mountain mostly points up the cowboy era. Two characters in the movie, Ennis and Jack, are cowboy figures reflecting the characteristic of cowboy life. They perform what American cowboys look like through their attitudes, clothes, occupation, and so forth. They fall in love to one another and this same-sex love relationship has become the challenge to their life as cowboy.

The challenge to cowboy myth is firstly presented through the love relationship between Ennis and Jack. At the beginning of their love story, Ennis who is characterized as a quiet person denied his appeal to Jack. His denial is shown through the dialogue below after the first night they have spent together:

Ennis: It's a one-shot thing we got goin' on here

Jack: Nobody's business but ours

Ennis: You know I ain't queer

Jack: Me neither

(Brokeback Mountain DVD, 00:32:02)

The word "queer"can mean weird. In this discussion, queer becomes the signifier to homosexuality. Ennis's denial is affected by the prejudice of being homosexual at that time. This denial is his response to his fear of social prejudice towards homosexuals. Moreover, his occupation as cowboy who herds cattle in the wilderness contradicts his love preference. Jack also gives similar response to the "queer" topic which means he realizes his position in this social life if his homosexuality becomes public.

Joe Aguirre: I ain't got no work for you.

Jack: Ennis Del Mare ain't been around, has he?

Joe Aguirre: You boys sure found a way to make the time pass up there. Twist, you guys wasn't getting paid to leave the dogs baby sit the sheep while you stemmed the rose.

(Brokeback Mountain DVD, 00:45:29)

The fear that people might learn about their relationship has made Ennis and Jack to act cautiously. Joe Aguirre tells Jack that he finds out about what they did in Brokeback Mountain by saying "stemmed the rose"which represent the sexual intercourse between them. The word "stemmed" is signifier to the signified phallus, whereas "rose" plays as signifier to anus. These words come together and create the signification of sexual intercourse.

The hatred from witnessing Ennis's and Jack's love relationship is another way to show how society respond to homosexual. Thus, Joe's rejection to hire Jack for another summer work is influenced by his prejudice towards gays. Joe believes that a cowboy should be able to stand as man of trust, especially to accomplish his responsibility which in this case is his duty to herd cattle in Brokeback Mountain. Realizing that Jack is gay, Joe decides to not hire him anymore and it means that he does not put his trust in Jack to play his role as a reliable cowboy.

Living the life as cowboy demands huge responsibility, especially by fulfilling the idea of traditional love. The challenge is 
even greater because Ennis and Jack could not escape from social expectation which is to bring their traditional love into marriage. As symbol of conventional relationship, marriage brings a man and a woman together, therefore Ennis and Jack decide to marry women in order to gain acknowledgement from people that they uphold traditional love.

Starting the conventional relationship means a man should plan to marry a woman, as Ennis says, "Like I said, me and Alma is getting married in November?" (Brokeback Mountain DVD, 00:41:32). In order to fulfil the expectation to establish conventional marriage, Ennis has decided to get marry soon. Jack shows the similar reaction towards this topic by stating, "I married the prettiest little gal in Childress, Texas" (Brokeback Mountain DVD: 01:04:35).The word "marry" and "married" both become the sign of normal couple, normal family, and normal life. This is how society depicts the concept of being a man.

Although they finally commit themselves in marriage, Ennis and Jack do not stop from being love partner. It then becomes another reason why cowboy myth meets its challenge again.

Ennis: You and Lureen, it's normal and all?

Jack: Sure.

Ennis: She don't ever suspect?

Jack: (shakes his head).

(Brokeback Mountain DVD, 00:45:29)

Ennis's word of "normal" signifies the circumstance of Jack's conventional marriage. He ensures that there is no suspicion from Jack's wife about their relationship. Ennis and Jack show hard struggle to keep their responsibility as man in society and to play their role as the head of a traditional family.
This struggle is a sign of preserving the cowboy's character as a man of honour. Although Ennis and Jack establish the conventional relationship with women and get married to them, being homosexual still distract their effort in maintaining the cowboy character. Their love concept invites refusal from people, even though they have shown them through conventional marriage and traditional relationship.

Cowboy's toughness is considered by his hard and lonely life. The idea of hard and lonely life are derived from the cowboys' experience in living in the isolated environment andlive far away from civilization like staying in the wilderness during the sheep herding. The lonely life of cowboy that is mostly spent in isolated areas builds their self-dependence. In contradictory to this description, Ennis and Jack decide to keep working in Brokeback Mountain every year to have more freedom to express their true feeling toward each other.

"Brokeback Mountain" is mentioned many times throughout the movie, this is the sign of hard work, endurance, individualism and more importantly freedom. In the connection with cowboy myth, Brokeback Mountain represents cowboy's courageous spirit which refers to his toughness. Herding cattle, fishing and hunting are common matters for cowboy when they are in this wilderness and these adventurous activities symbolizes the manliness of cowboy.

For different reasons, Brokeback Mountain brings in singular meaning for Jack and Ennis. Brokeback Mountain is still a signifier for freedom, but this is deciphered in different viewpoint. The secluded mountain provides shelter for Ennis and Jack to expose their feelings and show their affection without restraint. The silent atmosphere absolves them in communicating their love without dread of 
Volume 2, Nomor 2, Desember 2021

being witnessed by people. They can ignore the established prejudice and just become who they truly are.Hence, the signification ofBrokeback Mountain results in divergent meanings in the context of cowboy myth and how it is challenged.

\section{CONCLUSION}

The love story in Brokeback Mountain reflects an obvious part regarding public reaction toward homosexuals at particular time. Ennis and Jack indulge their feelings by keeping their passionate relationship. However, as cowboys, they must maintain their characters expected by society and they try hard to play their roles as man by enduring traditional relationship and conventional marriage with women. Playing their role in the traditional life, yet staying committed with their homosexual relationshipsomehow become significant reference to the challenge to cowboy myth and it contradicts the expected characters of cowboy as formed within social perspective.

\section{REFERENCES}

Barthes, Roland. 1999. Mythologies. Translated by Annette Lavers. New York: Hill and Wang.

Creswell, J. W. 2009. Research Design: Qualitative, Quantitative, and Mixed Method Approach. USA: SAGE Publication.

Fejes, Fred. 2008. Gay Rights and Moral Panic: The Origins of America's Debate on Homosexuality. New York: Palgrave Macmillan.

Lee, Ang. 2005. Brokeback Mountain. USA: Focus Features and River Road Entertainment.
Monaco, James. 2000. How to Read a Film. New York: Oxford University Press.

Nackbar, Jack, and Kevin Lause. 1992. Popular Culture: An Introductory Text. Bowling Green: Bowling Green University Popular Press.

Savage, William W. 1993. Cowboy Life: Reconstructing an American Myth. USA: University Press of Colorado.

\section{Encyclopaedia Americana International} Edition: Volume 8. Connecticut: Scholastic Library Publishing, Inc. 